\title{
University Students' Preferences about Savings and Investments at Individual and National level in the 21st Century: The Case of Turkey
}

Aynur Yumurtaci ${ }^{1}$, Bilal Bagis ${ }^{2}$

\begin{abstract}
This paper aims to capture the favored both national and individual saving and investment perceptions of the Turkish youth. Also, the research contributes to the understanding of the common preferences of the youth and focuses on perceptions over their home country's saving-investment decisions. We reason, it is important to evaluate views of the youth on national savings and investments as they will be both the decisionmakers determining the economic and social policies of the near future and the ones that are directly impacted by these policies implemented today. For this purpose, a questionnaire is applied to randomly selected 550 university students in Turkey and the results are analyzed by the chi-square test. Accordingly, students have mostly preferred that investments should be primarily made to the education sector at national level while investment made for the social security system is placed on the last rank. In addition, education is the most important individual investment choice of participants. On the other hand, information technologies, energy, and agriculture are identified as the most significant investment areas, which could be potentially increased the global competitiveness of their home country. Another important outcome of this research is that students prefer to invest their individual savings in gold and real estate investments, respectively.
\end{abstract}

Keywords: Economic Policies, Investment, Saving, Turkish Economy, University Students.

JEL Classification: D6, E2, H3, H5, I3

Received: 13 November 2019 / Accepted: 9 October 2020 / Sent for Publication: 7 December 2020

\section{Introduction}

Some developed economies and many of their emerging counterparts, including Turkey, have long had to deal with huge twin deficits of the fiscal and current account. Accordingly, both the investment and saving decisions and the corresponding policies are usually met with harsh criticism. These deficits, and the accompanying financing needs, lead to more fragile national economies and financial markets (Morgan Stanley, 2013).

\footnotetext{
${ }^{1}$ Corresponding Author: Ph.D., Istanbul University, Faculty of Economics, Turkey, aynur.yumurtaci@gmail.com, ORCID ID: 0000-0003-0277-5750.

2 Visiting Asst. Prof., UC Berkeley, Department of Economics, Berkeley, CA, The United States of America. bilalbagis@yahoo.com, ORCID ID: 0000-0003-2314-8991.

(C) 2020 by the authors; licensee Review of Economic Perspectives / Národohospodářský obzor, Masaryk University, Faculty of Economics and Administration, Brno, Czech Republic. This article is an open access article distributed under the terms and conditions of the Creative Commons Attribution 3.0 license, Attribution - Non Commercial - No Derivatives.
} 
To be more precise, huge expenditures by the private sector and the public, including the investment expenditures, are not well met with the domestic savings rates. Saving behaviors and investment decisions are therefore of significant importance, not only in terms of performance of the administrators, but also for the future macro-resilience and the ultimate welfare of the public.

In this context, and considering the relatively complicated recent trends in the world economy, the public (including the youth) needs to assume an active and smarter role or at least aim to have a say on national investment plans. ${ }^{3}$ After all, inadequate savings and investments could eventually force the country to resort to the much costlier external resources in an effort to ensure the much-needed higher growth. These external funds, in return, could potentially destroy the balance of economic and social welfare considering all the incurring costs and burden (Bagis, 2019). These attempts, in return, would inevitably put significant pressure on the public by increasing the debt burden.

In this respect, we contemplate assessment of the opinions of young people, who would make future policy makers, regarding the national saving and the preferred areas of investments as the bare minimum. This is mainly because a successful redirection of national savings to the most strategic investment areas is a critical factor that will determine the power of the country on the global economic, social, and political platforms. In this context, growth of savings and choices regarding investments is also decisive in the future economic welfare of national economies. Thus, it is suggested that the welfare economics practices, which are formed by considering the preferences of the individuals, should also be taken into consideration in determining the national investments and savings. These suggested policy shifts would create an important economic externality both at the national and international level.

A brief literature review shows that, despite its importance and apart from the individual saving and investment behavior, there are actually not many studies investigating the direction in which national savings and investments should be headed, taking individual preferences into consideration. On the other hand, the literature review also demonstrates that studies on students' own savings and investment tendencies are at a significant number. In this line, numerous researchers have drawn attention to the importance of savings and investments for the national economies and have carried out various empirical as well as theoretical studies on this matter.

Both the individual and the national saving-investment (S-I) decisions are, therefore, crucial for national economies. Modern economies are still far from a utopic world where investment and saving attitudes would not matter at all. After all, as famously pointed out by Feldstein and Horioka (1980) and given the current evidence over imperfect capital mobility, national savings and investments are of critical importance for macro and financial stability as well as the growth potential of the national economies (Feldstein \& Horioka, 1980).

Discussions over savings and investment preferences have also been an important issue in both its individual and social dimensions. In this context, social and economic policy experts and especially the economists have a critical role to play in determining these

\footnotetext{
${ }^{3}$ An active role to influence public policies may vary from taking part in simple public opinions to NGOs, think-tanks or even more active participation in public discussions.
} 
saving and investment relations. However, individual preferences always have a decisive effect on shaping public saving and investment decisions. In other words, even at macro level, saving and investment preferences of individuals may determine macro outcomes such as the global competitiveness of the home countries.

Based on findings in this survey analysis, we argue that it is of critical importance to correctly assess and evaluate the opinions and behaviors of individuals regarding not only their individual interests, but also in terms of their preferences for regarding national investments and savings. This could, maybe, be achieved by creating public opinion surveys in the process.

Meanwhile, it is also crucial to understand and accurately assess the S-I preferences of the youth that will take critical policy making roles in the near future. As a reference point, views of the university students (youth in their early twenties) might also provide a new perspective for legislators and professionals.

In this study, it is aimed to capture the favored both national and individual saving and investment perceptions of the Turkish youth. Therefore, the paper aims to understand the current trends and build a new vision looking forward. In this direction, the next generation is selected for our survey, since it is mainly these participants that will be directly influenced by economic policies of today and that they will be the future managers, leaders, employers and employees that will play a significant role in determining the S-I decisions in the $21^{\text {st }}$ century of Turkey. They are also the future of this country, not just as the policymakers but also as the ones that will be impacted by the policies implemented today.

In this study, firstly, the literature including theoretical and field studies related to S-I is examined. Then, the results of our field research are given. In this survey analysis, first, students are asked about their preferences over self-saving and investment habits. The survey focuses on students' perceptions of national S-I behavior and their respective thoughts over national economic policies.

\section{Literature review}

Most of the existing literature on S-I perceptions focuses on individual self-preferences while a limited number of others deal with national policy choices and the economic policies implemented. The literature predominantly underlines the impact of various socio-economic and demographic factors on individual self-investment preferences in general, but not much over the national investment choices. For example, in Mahdzan \& Tabiani (2013) and Mudzingiri et al. (2018a), financial literacy and education levels are considered as the most significant factors determining S-I behaviors (Mahdzan \& Tabiani, 2013; Mudzingiri et al., 2018a).

In another extensive survey analysis, in terms of individual vs. group behaviors, Falk et al. (2018) warns of significant variations in economic preferences due to changing characteristics, cultural, religious and social factors. Their well-rounded survey analysis, over eighty-thousand people from seventy-six nations, reveals considerable inter and inner-country heterogeneities across various individual and socio-economic factors, when it comes to individual behaviors and economic preferences of people. As an important 
result of the study, conventional instruments of gold, silver, and real-estate are found as the primary instruments of saving in many developing and least-developed economies.

Meanwhile, according to Jamel et al. (2015), for instance, some other factors such as the (socio-economic and socio-demographic) family structure, interests in financial matters and even peer influence do actually shape student perceptions regarding S-I (Jamel et al., 2015). In the Indian case, Bhat (2018) analyzes preferences among various educational and age groups of youth towards financial investment. In this study conducted over 220 students in the Anantnag Jammu and Kashmir districts in India, Bhat (2018) shows that youth is mostly aware of their financial investment options and their preferences. In addition, real estate and gold are the main investment preferences of the Indian youth (Bhat, 2018).

On the other hand, Atchyuthan \& Yogendrarajah (2017) focus on investment awareness and preferences of the working women in the Jaffna district in Sri Lanka. Accordingly, Jaffna's working women are well aware of the investment avenues, but they mostly depend on their husbands in their investment decisions. Investment preferences of participants are mostly concentrated on bank deposits and gold investment avenues (Atchyuthan \& Yogendrarajah, 2017).

Another question in mind would be whether occupations would matter. Bhavsar (2013) carries out a study over S-I approach of 100 school teachers. Survey outputs show that teachers use their savings predominantly on bank deposits, gold, and silver respectively. Moreover, they intend to use these investments towards the education and marriage of their children in the future (Bhavsar, 2013).

In other studies, demographic differences are defined as other types of factors that should be considered in revealing investment preferences. For example, Bayyurt et al. (2013) examine gender differences in investment preferences. The survey is conducted over 2036 (635 female, 1431 male) Turkish participants and reveals that men participants mostly prefer common stocks and real estate for investment, while women participants are more risk-averse and hence choose investment funds, time deposits, and gold (Bayyurt, et al., 2012). Also, Ciftci (2017), on the other hand, investigates investment preferences of the generation $\mathrm{Y}$. This analysis is conducted over 668 people and shows that the most preferred investment area of generation Y is also gold actually (Ciftci, 2017).

Saving and consumption behaviors of Generation Y are also investigated by Ganesan (2012) in Malaysia. This study is conducted on 592 participants aged between 19-32 in major cities of Malaysia and shows that the Malaysian Generation Y saves almost 24,63 percent of their monthly income. This saving rate is nearly the same as that of the national average. Malaysian Generation Y generally invested their savings in gold ( 13,1 percent) and trust units (15,6 percent). Primary investment preferences of Generation Y are sorted for emergency and unforeseen circumstances; future investment, vacation, wedding, and retirement, respectively. Only a small percentage of Generation Y prefers to use their savings towards business investments (Ganesan, 2012).

Another aspect of the issue, the S-I decision in terms of the economic development of the countries is also evaluated extensively in the literature. The developed economies case is a little different. Saving rates are usually very low. Savings and investments are usually not correlated, and preferences may vary a lot. A good example, in this case, is Dolphin's 
(2012) survey of the financial future of the British youth. At first, an online questionnaire aimed to investigate the youth's saving behavior, is conducted among 1504 young Britons. In this context, an online questionnaire is directed to the 16-29 aged group whose income level is lower than the national median income. Second, three workshops are organized, each with 18 young participants in attendance: One with 16-22 age group with less than the median income in Manchester, another with 19-25 age with a range of incomes in London, and the third one with 22-29 aged group with less than the median income in Midsomer Norton. Finally, an interview is organized with ten stakeholders so that they take expert's (government officials, academics, representatives from youth organizations, etc.) knowledge about financial challenges facing these young people. According to basic results, actually one-fourth of the participants don't have any savings, and also one-third of all age groups have less than $£ 100$ in savings. Interviews with young people supported the same findings. Also, more than 60 percent of students who cannot make savings say that they cannot afford to save. Another important finding is that family is the main determining factor (determiner) in their investment preferences (Dolphin, 2012).

As yet another example, Balint \& Horvathne Kokeny (2013) also investigate saving tendency of 323 Hungarian College Students. First of all, it is observed that financial culture is not well-founded among the students. On the other hand, parental and educational influences have a rather significant impact on subsequent financial perspective of students and their saving tendencies. In this context, it is emphasized that financial literacy should definitely be improved for the students in the primary schools (Balint \& Horvathne Kokeny, 2013).

Differences between university students and the other younger generations in terms of their S-I preferences are another aspect of the question. Anak Wong (2013) examines practices of saving among secondary education, college, and university students using a total of 300 students. According to the survey, saving practices are indeed increasing by the education level. In particular, the secondary school students save less compared to the other groups. College or university students, on the other hand, show more saving responsibility than the secondary school students in terms of budgeting and managing their expenditures. As a noteworthy outcome of this survey, university students are found to be the most conscious group in terms of saving perceptions among all the three groups of students (Anak Wong, 2013). This is, most probably, because they usually have more experience in managing and dealing with finances, compared to the other group of students.

In many developing and least-developed economies, financial literacy is a big issue. For instance, the spending and saving behavior of youth in Aurangabad city in India is investigated by Birari \& Patil (2014). In this study, conducted with 150 students from three categories (50 students from each of the junior, graduated, and post-graduate categories respectively), the age group of 14-30 is referred to as youth. The most important result of this study is that there is a generally low level of awareness among the students regarding saving or investment preferences and the meaning of their habits (Birari \& Patil, 2014).

In Turkey, Ozdemir et al. (2015) carry out an investigation on the financial literacy of over 221 students studying at the faculty of economics and administrative sciences at 
Anadolu University. With this study, they aim to understand the university students' future financial manners and hence the behavior that will shape the future of Turkish society. Accordingly, it is clear that there is no statistically significant relationship between gender and the financial literacy. On the other hand, the analysis results show that only 6.8 percent of the students had a low financial literacy level (Ozdemir et al., 2015).

On the other hand, financial literacy is usually a more profound issue for many African countries. Mireku (2015) analyzes financial literacy among university students in Ghana. Survey results point out that university students in Ghana show moderate knowledge over savings, despite the fact that they have a relatively low level of knowledge regarding the financial issues. In this context, it is emphasized that a new national financial literacy policy should be established in Ghana (Mireku, 2015).

Meanwhile, Mudzingiri et al. (2018b) show that lower levels of financial literacy may actually lead to more risky actions, too much confidence, and more aggressive preferences overall. This is usually the case for the advanced Western economies (Mudzingiri et al., 2018b).

Hietanen (2017) aims to seek answers in two different countries (Finland and the United Kingdom) and universities, regarding (a) whether university students do any investments, (b) how they saw investment decisions, and (c) what affects their investment behavior, etc. Survey outputs show that less than half of the students decide to invest in the financial markets in both countries, which could partly contain a risk-averse behavior. This outcome is assessed as an interesting finding because all participants of this survey came from business-related classes. In the meantime, investment encouragement for students comes from education in Finland, yet the UK students' investment behavior is mostly influenced by friends (Hietanen, 2017).

Overall, when the current literature is examined, it is clear that the most relevant studies are predominantly concerned with the personal S-I preferences of the youth; rather than the national S-I preferences the youth envisions for their home countries. This research is, therefore, the first attempt to our knowledge to understand the students' (and hence the youth's) S-I preferences for their respective countries. Even in some of those studies that do actually discuss this idea, these preferences have not been analyzed in depth.

\section{Methodology}

For survey analysis, a cross-sectional quantitative research method which is commonly preferred for social science surveys, is used with the help of a multiple-choice questionnaire. The questionnaire consisting of 32 (multiple choices) questions aims to assess preferences and perspectives towards both national and individual S-I. The questionnaire form contains three subjective groups of questions to evaluate the following three main issues;

1. Nine questions are related to "demographic data" about the students (e.g. age, gender, college years-grade, etc.).

2. Twelve questions are related to "socio-economic data" about students and their families (e.g. wage, scholarship, working conditions for both students and their families, etc.). 
3. Eleven questions are related to "S-I preferences" of the students (e.g., saving behavior, investment preferences, following financial news, etc.).

Questions in the third group, in particular, include students' self-perceptions over national S-I. This is important to get a general sense regarding the preferences and perceptions of the university students. First, the questionnaire has been tested on a control group, which contains 50 university students. According to the feedbacks obtained from students, the necessary corrections have been made, and the questionnaire has been applied. Participation in the questionnaire is voluntary from different cities and universities, and the questionnaires have been applied and collected face to face at one time. First, we explain to the students why this research is carried out. Then, we also provide some theoretical information about S-I. And then, we ask students to answer the questions. The questionnaire was randomly distributed to 550 volunteers who study different faculties. After the unfilled and incorrectly filled forms have excluded, 531 questionnaires have been saved for analysis.

The main criteria to determine the statistical methods used in research is whether parametric or non-parametric tests will be used in the analysis (Wells and Hintze, 2007). In our study, data are not normally distributed, so a non-parametric test is used for analysis. Pearson Chi-Square test is one of the methods as a non-parametric test, to be used when it is desired to evaluate whether there is a relationship between two selected variables or whether these two categorical variables are independent of each other. For the survey analysis, the Chi-Square Test is used in the SPSS 19.0 program. In addition, $p$ $<0.05$ is taken as a basis for the significance levels of the data obtained after the Chisquare Test. The hypotheses tested in this study are listed below.

H1: There is a meaningful relationship between economy-finance publications follow-up and age,

$\mathrm{H} 2$ : There is a meaningful relationship between economy-finance publications follow-up and gender,

H3: There is a meaningful relationship between students' saving behavior and income level,

$\mathrm{H} 4$ : There is a meaningful relationship between gender and the most important investment area preferences,

H5: There is a relationship between the choice of more needed investment area in Turkey and gender,

H6: There is a significant relationship between gender and the choice of the area where national savings should be directed to,

H7: There is a meaningful relationship between the choice of the investment area that will increase Turkey's global competitiveness in the 21 st century and gender,

H8: There is no significant relationship between being abroad and ideas regarding the area that needs investment the most in Turkey. 


\section{Results}

In this survey analysis, the total number of participants counted is 531, after missing valued questionnaires are excluded. According to the demographic data, 58,4 percent of these participants are women, and 41,6 percent are men. A significant portion of the participants are in the 21-24 age group, and the participants are mostly at their $2^{\text {nd }}$ grade $(34,7$ percent $)$ and $4^{\text {th }}$ grade $(34,8$ percent) (Table 1$)$.

Table 1. Socio-Demographic and Economic Characteristics of the Participants

\begin{tabular}{|c|c|c|}
\hline Gender & Frequency (f) & Percent (p) \\
\hline Female & 310 & 58,4 \\
\hline Male & 221 & 41,6 \\
\hline Age & Frequency (f) & Percent (p) \\
\hline $17-20$ & 73 & 13,7 \\
\hline $21-24$ & 415 & 78,2 \\
\hline $25+$ & 43 & 8,1 \\
\hline Grade & Frequency (f) & Percent (p) \\
\hline $1 s t$ & 88 & 16,6 \\
\hline $2 n d$ & 184 & 34,7 \\
\hline $3 r d$ & 74 & 13,9 \\
\hline $4 t h$ & 185 & 34,8 \\
\hline Monthly Income* & Frequency (f) & Percent (p) \\
\hline Under TRY 500 & 198 & 37,3 \\
\hline TRY 501-1000 & 218 & 41,1 \\
\hline TRY 1001-1404 & 59 & 11,1 \\
\hline TRY 1405-2000 & 27 & 5,1 \\
\hline TRY 2001-2500 & 7 & 1,3 \\
\hline Over TRY 2500 & 22 & 4,1 \\
\hline $\begin{array}{l}\text { Previous Experience Being } \\
\text { Abroad }\end{array}$ & Frequency (f) & Percent (p) \\
\hline Yes & 118 & 22,2 \\
\hline No & 413 & 77,8 \\
\hline Total & 531 & 100,0 \\
\hline
\end{tabular}

Once the monthly income level of the participants is evaluated, it is observed that 78,4 percent of participants (a total of 416 students) have a monthly income of under TRY 1000. A small portion of these participants has a monthly income of over TRY 2500 (Table 1). It has been seen that approximately one-fourth of the participants have experience of being abroad during their university years.

Before evaluating the students' individual and national preferences about S-I, we have wondered whether they are interested in economics and finance or not. Because the students' earlier interest in economics-finance issues may exhibit that they have some specific perspective on S-I. In this context, in addition to the demographic patterns of these students, participants are also questioned over whether they follow economy and finance-related publications. Survey analysis shows that 33,2 percent of female participants and 48,9 percent of male participants actually follow publications related to 
economy and finance (Table 2). There is also a positive relationship between economyfinance publication follow-up and gender $\left(\mathrm{p}=0.000<0.05, \chi^{2}=13,184, \mathrm{df}=1\right)$. Meanwhile, male participants had a relatively greater tendency to follow economy-finance publications.

Table 2. Follow up of Economics-Finance Publications by Gender and Age

\begin{tabular}{l|c|c|c|c|c|c}
\hline \multirow{2}{*}{ Gender } & \multicolumn{3}{|c|}{ Frequency (f) } & \multicolumn{3}{c}{ Percent (p) } \\
\cline { 2 - 7 } & Yes & No & Total & Yes & No & Total \\
\hline Female & 103 & 207 & 310 & 33,2 & 66,8 & 100 \\
\hline Male & 108 & 113 & 221 & 48,9 & 51,1 & 100 \\
\hline
\end{tabular}

$\left(\mathrm{p}=0.000<0.05, \chi^{2}=13,184, \mathrm{df}=1\right)$

\begin{tabular}{l|c|c|c|c|c|c}
\hline \multirow{2}{*}{ Age } & \multicolumn{3}{|c|}{ Frequency (f) } & \multicolumn{3}{c}{ Percent (p) } \\
\cline { 2 - 7 } & Yes & No & Total & Yes & No & Total \\
\hline $\mathbf{1 7 - 2 0}$ & 17 & 56 & 73 & 23,3 & 76,7 & 100 \\
\hline $\mathbf{2 1 - 2 4}$ & 172 & 243 & 415 & 41,4 & 58,6 & 100 \\
\hline $\mathbf{2 5 +}$ & 22 & 21 & 43 & 51,2 & 48,8 & 100 \\
\hline$\left.p=0.004<0.05, \chi^{2}=11,099, d f=2\right)$
\end{tabular}

In addition to the gender, there was also a strong positive relationship between follow-up of economy-finance publications and age $\left(\mathrm{p}=0.004<0.05, \chi^{2}=11,099, \mathrm{df}=2\right)$. When the follow-up of economy-finance publications is evaluated in terms of the age ranges in details, on the other hand, first of all, 51,2 percent of students aged 25 and over and secondly 41,4 percent of students in the 21-24 age group follow the publications related to economy and finance (Table 2).

When the income levels and saving habits of students are examined, it is observed that among all of the income groups, 184 out of 531 participants could save. Details of saving behaviors demonstrate that participants having income under TRY 500 are counted as ( 26,3 percent) out of 198 could be able to save. Meanwhile, 15 (68,2 percent) out of 22 participants who have an income level of over TRY 2500 stated that they could make saving (Table 3). Therefore, overall, there is a significant positive relationship between income level and saving behavior $\left(\mathrm{p}=0.001<0.05, \chi^{2}=21,341, \mathrm{df}=5\right)$.

Table 3. Income Level and Saving Behavior

\begin{tabular}{|c|c|c|c|c|}
\hline \multirow{3}{*}{ Income Level } & \multicolumn{4}{|c|}{ Can you save on your monthly income? } \\
\hline & \multicolumn{2}{|c|}{ Frequency $(\mathbf{f})$} & \multicolumn{2}{|c|}{ Percent (p) } \\
\hline & Yes & No & Yes & No \\
\hline Under TRY 500 & 52 & 146 & 26,3 & 73,7 \\
\hline TRY 501-1000 & 76 & 142 & 34,9 & 65,1 \\
\hline TRY 1001-1404 & 25 & 34 & 42,4 & 57,6 \\
\hline TRY $1405-2000$ & 12 & 15 & 44,4 & 55,6 \\
\hline TRY 2001-2500 & 4 & 3 & 57,1 & 42,9 \\
\hline Over TRY 2500 & 15 & 7 & 68,2 & 31,8 \\
\hline
\end{tabular}

In addition, further questions are directed to participants to understand their investment preferences, and the survey responses are then processed for relationship analysis. For 
example, it is observed that 151 out of 310 female participants and 86 out of 221 male participants considered "education" as the first investment choice. Although "education" and "health" constituted the primary investment choices of both genders, detailed comparative analysis of female participants with the male participants show that males show a higher tendency towards investment in "research and development" (Table 4). Among the participants, "social security" is considered as the least favored investment area. The analysis also show that, gender and most important investment area preferences show a close relationship among all of the Turkish students $\left(p=0.000<0.05, \chi^{2}=29,429\right.$, $\mathrm{df}=5)$.

Table 4. Primary Investment Preferences of Students by Gender

\begin{tabular}{|c|c|c|c|c|c|c|c|c|c|c|c|c|}
\hline \multirow{3}{*}{ Gender } & \multicolumn{12}{|c|}{ The Most Important Investment Area } \\
\hline & \multicolumn{2}{|c|}{ Education } & \multicolumn{2}{|c|}{ Health } & \multicolumn{2}{|c|}{$\begin{array}{c}\text { Social } \\
\text { Security }\end{array}$} & \multicolumn{2}{|c|}{$\begin{array}{c}\text { Real } \\
\text { Estate }\end{array}$} & \multicolumn{2}{|c|}{ Employment } & \multicolumn{2}{|c|}{$\begin{array}{c}\text { Research \& } \\
\text { Development }\end{array}$} \\
\hline & $f$ & $p$ & $f$ & $p$ & $f$ & $p$ & $f$ & $p$ & $f$ & $p$ & $f$ & $p$ \\
\hline Female & 151 & 48,7 & 81 & 26,1 & 15 & 4,8 & 33 & 10,6 & 17 & 5,5 & 13 & 4,2 \\
\hline Male & 86 & 38,9 & 50 & 22,6 & 7 & 3,2 & 26 & 11,8 & 12 & 5,4 & 40 & 18,0 \\
\hline
\end{tabular}

Following the individual investment preferences, a question has been directed to the students related to which areas need more investment in Turkey. Education is again the primary preference for both the male and female participants. In particular, $210(67,7$ percent) out of 310 female participants and 134 (60,6 percent) out of 221 male participants choose "education" as one of the main areas for national investment that need support the most. On the other hand, 1,4 percent of total male and 3,9 percent of total female participants choose "social security" as the least preferred investment area (Table 5). In this context, there is a relationship between the choice of a more needed investment area in Turkey and gender $\left(p=0.045<0.05, \chi^{2}=9,767, \mathrm{df}=4\right)$.

Table 5. Which Areas Need More Investment in Turkey?

\begin{tabular}{l|c|c|c|c|c|c|c|c|c|c}
\hline \multirow{2}{*}{ Gender } & \multicolumn{9}{c|}{ Which areas need more investment in Turkey? } \\
\cline { 2 - 11 } & Education & \multicolumn{2}{c|}{ Health } & \multicolumn{2}{c|}{ Real Estate } & \multicolumn{2}{c}{ Employment } & \multicolumn{2}{c}{$\begin{array}{c}\text { Social } \\
\text { Security }\end{array}$} \\
\cline { 2 - 11 } & $\boldsymbol{f}$ & $\boldsymbol{p}$ & $\boldsymbol{f}$ & $\boldsymbol{p}$ & $\boldsymbol{f}$ & $\boldsymbol{p}$ & $\boldsymbol{f}$ & $\boldsymbol{p}$ & $\boldsymbol{f}$ & $\boldsymbol{p}$ \\
\hline Female & 210 & 67,7 & 27 & 8,7 & 11 & 3,5 & 50 & 16,1 & 12 & 3,9 \\
\hline Male & 134 & 60,6 & 34 & 15,4 & 7 & 3,2 & 43 & 19,5 & 3 & 1,4 \\
\hline$(p=0.045<0.05$, & $\left.\chi^{2}=9,767, d f=4\right)$
\end{tabular}

In line with the findings above, another complementary question is asked to the participants regarding the area in which national savings might be directed to, in Turkey? Both male and female participants preferred "education" as the primary area where national savings might be directed to. Almost half of all participants want national savings to be evaluated as an educational investment. In particular, 102 male and 161 female students prefer education. Mining (for female) and tourism (for male) are the least preferred areas in which national savings should be directed towards (Table 6). Accordingly, there is a significant relationship between gender and the choice of area where national savings should be directed to $\left(\mathrm{p}=0.031<0.05, \chi^{2}=16,932, \mathrm{df}=8\right)$. 
Table 6. Which Investment Areas Should the National Savings be Directed to?

\begin{tabular}{l|c|c|c|c}
\hline \multirow{2}{*}{ National savings be directed to } & \multicolumn{4}{|c}{ Gender } \\
\cline { 2 - 5 } & \multicolumn{2}{|c}{ Frequency (f) } & \multicolumn{2}{c}{ Percent (p) } \\
\cline { 2 - 5 } Education & Female & Male & Female & Male \\
\hline Health & 161 & 102 & 51,9 & 46,2 \\
\hline Real Estate & 39 & 27 & 12,6 & 12,2 \\
\hline Infrastructure & 27 & 18 & 8,7 & 8,1 \\
\hline Energy & 18 & 10 & 5,8 & 4,5 \\
\hline Mining & 17 & 24 & 5,5 & 10,9 \\
\hline Agriculture & 2 & 10 & 0,6 & 4,5 \\
\hline Tourism & 11 & 11 & 3,5 & 4,9 \\
\hline National Defense & 15 & 6 & 4,8 & 2,7 \\
\hline
\end{tabular}

$\left(p=0.031<0.05, \chi^{2}=16,932, d f=8\right)$

From a different perspective, another question is asked to participants regarding the areas of investment that would increase Turkey's global competitiveness the most in the 21st century. Responses from female and male participants are intensively focused on "information technologies", "agriculture", "energy" and "education". Interestingly, both the female and male students think that investments in "aviation" and "health" will be the least effective in increasing the global competitiveness of Turkey in the $21^{\text {st }}$ century (Table 7). In this case, there is no relationship between the choice of the investment area that will increase Turkey's global competitiveness in the 21 st century and gender $\left(\mathrm{p}=0.169>0.05, \chi^{2}=10,336, \mathrm{df}=7\right)$.

Table 7. Which Investment Areas Would Increase Turkey's Global Competitiveness the Most in the 21st century?

\begin{tabular}{l|c|c|c|c}
\hline \multirow{2}{*}{$\begin{array}{l}\text { Which Investment area will } \\
\text { increase Turkey's global } \\
\text { competitiveness in the 21st } \\
\text { century? }\end{array}$} & \multicolumn{4}{|c}{ Gender } \\
\cline { 2 - 5 } & \multicolumn{2}{|c|}{ Frequency (f) } & \multicolumn{2}{c}{ Percent (p) } \\
\cline { 2 - 5 } Agriculture & Female & Male & Female & Male \\
\hline Aviation & 50 & 29 & 16,1 & 13,1 \\
\hline Mine & 18 & 20 & 5,8 & 9,0 \\
\hline Energy & 36 & 21 & 11,6 & 9,5 \\
\hline Logistic & 50 & 46 & 16,1 & 20,8 \\
\hline Health & 30 & 22 & 9,7 & 10,0 \\
\hline Information Technology & 24 & 15 & 7,7 & 6,8 \\
\hline Education & 54 & 48 & 17,4 & 21,7 \\
\hline
\end{tabular}

$\left(p=0.169>0.05, \chi^{2}=10,336, d f=7\right)$ 
On the other hand, we have also evaluated the investment preferences of students who have been abroad before and those that have never been to. We also analyze whether there is any significant difference between the two groups. Accordingly, it is observed that students who have never been abroad mostly prefer to invest in gold and real estate. On the other hand, students who have been abroad prefer to invest in currency and gold. In addition, gold and currency investments are equally important for students who have previously been abroad (Table 8). However, the most important investment choice of students who have never been abroad is again gold. Investments made for individual pension system are preferred as the areas where the lowest level of investment is required for both groups.

Table 8. Relationship between Going Abroad and Investment Preferences

\begin{tabular}{l|c|c|c|c}
\hline \multirow{2}{*}{$\begin{array}{l}\text { If you had cash savings in the long } \\
\text { run, which would you invest? }\end{array}$} & \multicolumn{4}{|c}{ Have you ever been to abroad as a university } \\
student?
\end{tabular}

Meanwhile, on the basis of other empirical studies we have examined in the literature section, the possibility of parental influence as a determining factor in the investment preferences of young people was taken into consideration. In this context, also, students have been queried for their parents' investment preferences. Real estate has been a first investment choice for both mother's and father's. While the first investment preferences of students has been gold and second one has been real estate which might be accepted as a partial effect of parents on students' investment choice.

Being abroad could be effective in terms of directly observing the investment preferences of different societies and determining a broader perspective on investments. Accordingly, we ask another question to all of the students, including those that have been abroad before and those that have never been abroad, regarding the area they think investments should be made more in Turkey. All students (including those that have been abroad and those that have never been abroad) think that, in Turkey, investments should primarily be directed towards the education sector, in particular. Students, who have never been abroad before, have chosen social security as the least necessary area for investment. On the other hand, students who have been abroad before preferring real estate as the least necessary investment area in Turkey. (Table 9). In this context, there is indeed a relationship between being abroad and the choice regarding the area needing investment the most in Turkey $\left(\mathrm{p}=0.027<0.05, \chi^{2}=10,966, \mathrm{df}=4\right)$. 
Table 9. Relationship between Being Abroad and Ideas about the Area that Needs Investment the Most in Turkey

\begin{tabular}{l|c|c|c|c}
\hline \multirow{2}{*}{$\begin{array}{l}\text { Mostly Needed Investment Area } \\
\text { in Turkey. }\end{array}$} & \multicolumn{4}{|c}{ Have you ever been to abroad as a university } \\
student?
\end{tabular}

$\left(p=0.027<0.05, \chi^{2}=10,966, d f=4\right)$

To sum up, when the hypotheses are evaluated according to the survey outcomes, it is found that;

H1 can be "confirmed" because there is a meaningful relationship between economyfinance publications follow-up and age.

$\mathrm{H} 2$ can be "confirmed" because there is a meaningful relationship between economyfinance publications follow-up and gender,

H3 can be "confirmed" because there is a meaningful relationship between students' saving behavior and income level,

H4 can be "confirmed" because there is a meaningful relationship between gender and the most important investment area preferences,

H5: can be "confirmed" because there is a relationship between choice of more needed investment area and gender,

H6: can be "confirmed" because there is a significant relationship between gender and the choice of the area where national savings should be directed to,

$\mathrm{H} 7$ cannot be "confirmed" because there is no meaningful relationship between choice of the investment area that will increase Turkey's global competitiveness in the 21 st century and gender,

H8 cannot be "confirmed" because there is a significant relationship between being abroad and ideas about the area that needs investment the most in Turkey.

\section{Discussion}

In the related literature, relevant research has mostly focused on individual S-I behaviors and financial literacy trends. Many of these studies, which are explained briefly in the literature section and also partly here, have analyzed how individuals utilize their own savings, the family effects on students' saving behavior or just the students' saving preferences or performances, etc.

Meanwhile, a simple comparison of the relevant literature and our survey outputs leads to a number of distinctive results in our analysis. Cross-country differences in financial literacy are one factor to bear in mind here. For example, Bhat (2018) states that a significant majority of the Indian youth demonstrate an adequate level of information 
regarding their own financial investments and preferences. Also, Ozdemir et al. (2015) show that only 6,8 percent of the Turkish students have a low level of financial literacy. These findings are in contrast to that in Mireku (2015). According to Mireku (2015), African students have relatively very little information about financial issues. This is also in line with Birari \& Patil (2014)'s analysis, which is conducted over the Indian students. However, in our study, it is observed that university students exhibit a relatively high financial awareness, and further increasing with the age factor, regarding S-I decisions.

On the other hand, despite the confusing data and survey outcomes from some Asian economies such as India, many developing Asian economies are known for their relatively high saving rates (Horioka \& Terada-Hagiwara, 2012). However, the developed economies case is a little divergent. In particular, while Asian tigers and many other developing Asian countries are known for their high saving rates, the saving habit in developed countries is relatively low compared to their developing and underdeveloped counterparts. Dolphin (2012), for instance, shows that the saving habits of young people aged between 16-29 in Britain are not actually strong. Likewise, Hietanen (2017) shows that barely less than half of the students in Finland and the United Kingdom tend to invest. However, as another significant result of our analysis, we observe that students' tendency to invest increases by income level. In this case, it is concluded that at least more than half of the Turkish students are doing better in terms of financial literacy compared to their Finnish and British counterparts.

Moreover, according to the results in Bhat (2018) for India, Ganesan (2012) for Malaysia and Ciftci (2017) for Turkey, young generations (especially the Y generation) tend to have a basic investment choice of traditional gold instrument. Likewise, Atchyuthan \& Yogendrarajah (2017) also confirms the primary investment choice of gold for women, just as in many other underdeveloped or developing economy examples. Falk et al. (2018) also support the idea that the primary source of investment for those living in underdeveloped and developing economies is usually gold. Additionally, Bayyurt et al. (2013) confirm the risk-loving attitudes of men in that men participants tend to prefer common stocks and real estate while women participants tend to choose investment funds, time deposit, and gold for investment. In our analysis, preferences revealed in survey are no different compared with the examples provided in the literature. In particular, gold is again selected as a primary investment tool by university students in Turkey.

In our survey, we also ask students to determine the areas in which they think national savings should be directed to as an additional investment. Without any gender, age, or income distinction, a significant portion of the students choose "education" as the first choice of investment. It is concluded that students choose education as the primary area of national investment because they think transformation and success of education will eventually increase financial awareness and also global competitiveness (Ozturk, 2001; United Nations, 2020). Using evidence from various surveys, Mahdzan \& Tabiani (2013), Mudzingiri et al. (2018a), and Anak Wong (2013) also support the perception that the public believes education improves financial attitudes and behaviors.

There is an important synchronization between the individual investment preferences of the students and their thoughts about the areas where national investments should be directed. From this point of view, university students prefer to use their savings in gold and consider to direct their investments to education. Despite the consensus underlined 
above over the idea that national savings should primarily be directed towards education at the national level, there are still varying views over what areas should the investment be made in the context of sustainability of global competitiveness. According to the students, investment areas that are more likely to increase the global power of Turkey are information technology, energy, and agriculture, respectively. As compared with male participants, female students are much more adopted the idea of investment made for education. Hence, they also believe that education might increase the global competitiveness of Turkey.

On the other hand, it is also observed that parents' decisions are partially effective on students' opinions regarding the investment areas where national savings should be directed to in Turkey, which is similar to Dolphin (2012) and Hietanen (2017). These findings are, indeed, also in line with Jamel et al. (2015) and Balint and Horvathne Kokeny (2013). We reason this result has much to do with the traditional structure and labor division nature of the Turkish families.

Once our survey outcomes and the related literature are analyzed comparatively, the following analytical results may be summarized as follows. It is clear that most of the literature emphasizes the importance of "education" for saving behavior and also shows a positive correlation between the income level and saving habits. On the other hand, cultural and national differences are also found as one of the most important determinants of saving and investment behaviors, as well as the perceptions regarding national policy choices.

\section{Conclusion}

This research aims to approach and critically analyze a crucial national economic policy issue, the national S-I, from a different perspective. Relevant literature predominantly examines individual S-I habits in its micro dimensions that apply to the individuals mainly. On the other hand, in our study, individuals are expected to evaluate national S-I in its macro dimensions, additionally and beyond their own S-I habits. It could also be assumed a case study where these young people would have a decisive role in choices regarding national S-I. Our research, in this sense, has an innovative, unique perspective.

Survey analysis demonstrates that among the Turkish university students, male participants have a relatively greater tendency to follow economy-finance publications. It also shows that, among the participants, "social security" is considered as the least favored investment area. This is clearly an outcome of the nature of the public social security system in Turkey that covers all citizens.

Gold and currency investments, both of which are portable instruments, seem to be equally important for students who have previously been abroad. However, the most important investment choice for students who have never been abroad is the traditional investment instrument of gold. This is, indeed, no surprise as gold investments are usually considered as the traditional tendency of the Turkish households. Traveling and experiences abroad seem to slightly change that tendency.

Given this survey outcomes, and considering the individual saving and investment habits of young people in the literature, we conclude that it is important to consider the youth's concerns regarding national S-I. This policy suggestion is worth contemplating, in 
particular considering that these young people will be the main beneficiaries of the current S-I decisions. Meanwhile they will also be the ones deciding the future national S-I plans as the future policy makers. The paper provides evidence from Turkey where currentaccount deficits had for decades and even centuries been very high. Savings would be directed to the most efficient sectors to support effective investments and help Turkey stand out in global competition by reducing the current account deficit.

This survey analysis also shows that there is still room for improvement in financial literacy and education. It is also clear that there is still a significant need for extensive research over policies and tools to improve on the financial outcomes and the preferences over national S-I decisions. As Sabharwal (2016) shows, most students are actually aware of the importance of S-I decisions, but they usually need a concrete plan and policy as a nudge to start saving or decide which investment options would serve their and their country's interest the best.

This research is, meanwhile, intended to benefit the future researcher, policy's and investment firms alike in understanding the importance of S-I choices that could potentially increase the countries competitiveness in the global economy. The survey aims both to understand the current S-I trends among the Turkish youth and also to build a new and more acceptable (broadly acceptable) vision for the future. In this direction, it should be beneficial in terms of determination of future investment perspectives from the point of view of the young people.

We conclude that there are actually a lot of reasons to be optimistic when it comes to financial literacy and saving habits of the Turkish youth. Financial literacy in Turkey is relatively high, and saving rates have recently been increasing. On the other hand, in terms of national S-I perceptions, policy choices, and efficient use of national savings, Turkey is still lacking in utilizing its full potential. There is still much to benefit from regarding the welfare economics practices and proper utilization of the positive social and human capital potential.

According to the findings obtained from this study, a much more priority might be given to education investments in Turkey. In the long term, education has an important potential being a locomotive sector for other investment fields, and directing individual and national savings to education investment can be expected to have a significant impact on the economy (King, 2011). In sum, it is suggested that further studies might be carried out by making a faculty distinction to provide more comprehensive results.

Conflict of Interest: No potential conflict of interest was reported by the authors.

\section{References}

ANAK WONG, B. (2013). Practices of Savings among Students. Universiti Malaysia Sarawak, Master in Business Administration, Malaysia.

ATCHYUTHAN, N., YOGENDRARAJAH, R. (2017). A Study of Investment Awareness and Preference of Working Women in Jaffna District in Sri Lanka. Asia Pacific Journal of Research. I(LI), 15-113. 
BAGIS, B. (2019). Yeni Donemin Finansman Araclari SETA Analiz, September 2019. No 294. ISBN: 978-605-7544-82-7.

BALINT, A., HORVATHNE KOKENY, A. (2013). Saving Habits of Hungarian College Students. European Scientific Journal. 9(34), 83-92.

BAYYURT, N., KARIŞIK, V., COŞKUN, A. (2013). Gender Differences in Investment Preferences. European Journal of Economic and Political Studies 6(1), 71-83.

BHAT, A. A. (2018). Preferences of youth towards financial investment in (A Case study of District Anantnag Jammu and Kashmir). Management and Economic Journal, MEj 2018_02.06, 331-337.

BHAVSAR, H. N. (2013). A Study of Saving and Investment Pattern of School Teachers with special reference to Ahmednagar City, Mahartshtra. IBMRD's Journal of Management and Research. 2(1) March 2013, 256-267.

BIRARI, A., PATIL, U. (2014). Spending \& Saving Habits of Youth in the City of Aurangabad. The SIJ Transactions on Industrial, Financial \& Business Management (IFBM). 2(3) May 2014, 158-165.

CIFTCI, C. (2017). Generation Y Investment Tool Preferences: Game Theory Approach. Karabuk University Journal of Institute of Social Sciences. 7(2), 698-712.

DOLPHIN, T. (2012). Young People and Savings A Route to Improved Financial Resilience. Report, London: IPPR.

FALK, A., BECKER, A., DOHMEN, T., ENKE, B., HUFFMAN, D., SUNDE, U. (2018). Global Evidence on Economic Preferences. The Quarterly Journal of Economics. 133(4), 1645-1692. DOI: $10.1093 / q j e / q j y 013$

FELDSTEIN, M., HORIOKA, C. (1980). Domestic Saving and International Capital Flows. The Economic Journal. 90 (358) (Jun., 1980), 314-329. Blackwell Publishing for the Royal Economic Society. DOI: 10.2307/2231790

GANESAN, A. S. (2012). Consumption, Spending and Investment Behaviour of Malaysia Generation Y. Universiti Tunku Abdul Rahman Faculty of Accountancy and Management, Master of Business Administration, Malaysia.

HIETANEN, T. (2017). University Students' Attitudes towards Investing: A Comparison Between the United Kingdom and Finland. Helsinki Metropolia University of Applied Sciences Bachelor of Business Administration European Business Administration Thesis. Finland.

HORIOKA, C. Y., TERADA-HAGIWARA, A. (2012). The Determinants and LongTerm Projections of Saving Rates in Developing Asia. Japan and the World Economy. 24(2), 128-137. DOI: 10.1016/j.japwor.2012.01.006

JAMEL, A. A. A., RAMLAN, W. K., KARIM, M. A., MOHIDIN, R., OSMAN, Z. (2015). The Effects of Social Influence and Financial Literacy on Savings Behavior: A Study on Students of Higher Learning Institutions in Kota Kinabalu, Sabah. International Journal of Business and Social Science, 6(11) (1), 110-119. 
KING, E. (2011). Education is Fundamental to Development and Growth. [online]. [Accessed on 2020-07-10]. Retrieved from: https://blogs.worldbank.org/education/education-is-fundamental-to-development-andgrowth.

MAHDZAN, N.S., TABIANI, S. (2013). The Impact of Financial Literacy on Individual Saving: an Exploratory Study in the Malaysian Context. Transformations in Business \& Economics, 12(1) (28), 41- 55.

MIREKU, K. (2015). Financial Literacy among University Students: Evidence from Ghana. Kwame Nkrumah University of Science and Technology, Department of Accounting and Finance. Doctoral Thesis.

MORGAN STANLEY, (2013). Tales from the Emerging World. [online]. [Accessed on 2019-05-27]. Retrieved from: https://www.morganstanley.com/public/Tales_from_the_Emerging_World_Fragile_Fiv e.pdf

MUDZINGIRI, C., MWAMBA, J. W. M., KEYSER, J. N. (2018a). Incentivized Time Preferences, Level of Education in a Household and Financial Literacy: Laboratory Evidence. Journal of Economics and Behavioral Studies. 10(2), 103-119. DOI: 10.22610/jebs.v10i2(J).2220

MUDZINGIRI, C., MWAMBA, J. W. M., KEYSER, J. N. (2018b). Financial Behavior, Confidence, Risk Preferences and Financial Literacy of University Students. Cogent Economics \& Finance. 6(1), 1-25, DOI: 10.1080/23322039.2018.1512366

OZDEMIR, A., TEMIZEL, F., SONMEZ, H., ER, F. (2015). Financial Literacy Of University Students: A Case Study for Anadolu University, Turkey. Int. Journal of Management Economics and Business. 11(24), 97-110.

OZTURK, I. (2001). The Role of Education in Economic Development: A Theoretical Perspective. Journal of Rural Development and Administration. 33(1), 39-47.

SABHARWAL, K. (2016). Saving Habits of Graduates. International Journal of Social and Economic Research. 6(2) (April -June), 51-66. DOI: 10.5958/2249$\underline{6270.2016 .00016 .7}$

UNITED NATIONS (2020). Policy Brief: Education during COVID-19 and beyond. [online]. [Accessed on 2019-10-05]. Retrieved from: https://www.un.org/development/desa/dspd/wp content/uploads/sites/22/2020/08/sg_policy_brief_covid19_and_education_august_2020.pdf

WELLS, C. S., HINTZE, J. M. (2007). Dealing with Assumptions Underlying Statistical Tests. Psychology in the Schools, 44(5), 495-502. DOI: 10.1002/pits.20241 